Finnish university student activists' resources in student union activities: A Positive Youth Development (PYD) perspective

Ansala, Liisa $\$

University of Lapland, Finland (Liisa.Ansala@ulapland.fi)

Uusiautti, Satu

University of Lapland, Finland (atu.Uusiautti@ulapland.fi)

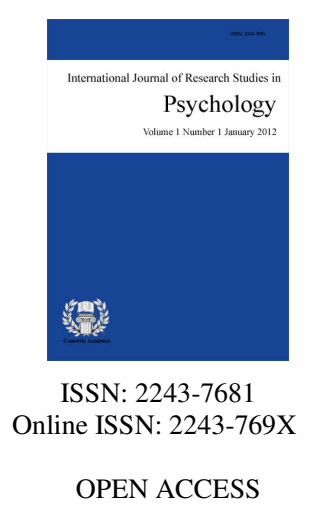

Received: 9 May 2016

Revised: 28 June 2016 DOI: $10.5861 /$ ijrsp.2016.1524

Accepted: 30 June 2016

\title{
Abstract
}

Active citizenship is an important political goal in the Finnish society. In this study, the challenges faced in student activism were studied through twelve student activists' narratives. The activists interviewed in this study were the chairpersons of the Finnish student unions at universities. The study leaned on the Positive Youth Development (PYD) theory. Challenges the interviewees mentioned were categorized into social, functional, emotion, and cognitive challenges and related resources. The positive coping with these challenges was analyzed through the elements of PYD. An especially relevant finding was that the student activists showed the development of active citizenship, which was contrasted as the sixth "C" of PYD, contributions to self, others, and society.

Keywords: Positive Youth Development; student activism; student unions; narrative research; positive psychology 


\section{Finnish university student activists' resources in student union activities: A Positive Youth Development (PYD) perspective}

\section{Introduction}

The youth's active citizenship and participation in surrounding community is a topic of increasing interest in politics and in youth research. Participation is considered a central feature of individual and communal development (Cicognani et al., 2008), and it makes a significant part of growth from childhood to adulthood (Flanagan \& Levine, 2010). Adolescence means time of practicing and learning active citizenship skills in various connections, such as volunteering, group activities, or participation in discussions (Flanagan \& Levine, 2010; Lerner et al., 2010). Late adolescence and young adulthood are periods when individuals define the basic values important to them and their future aspirations (Flanagan \& Levine, 2010). In this study, we focus on student activism during university studies. We are interested in analyzing what kinds of challenges student activists face and what kinds of resources they use to surpass them. The especial focus of the research is to discuss the positive development the university student activists' descriptions illustrate.

Traditionally, the concept of citizenship means a membership of a community (Marshall, 1950). It can also refer to a sense of belonging; in other words, to a group identity one adopts (Meglino \& Korsgaard, 2004). According to Delanty (2003), citizenship is something learnable and the civil rights are obtained simultaneously with equivalent duties. Voluntary organizational activities, such as student activism, include joint efforts for the common good, development of communalism among students, and learning of active citizenship skills (Ropers-Huilman, Carwile, \& Barnett, 2005).

Concepts like "a sense of community" (SoC) describe the sense of belonging to a group and social entities, such as mutual goal or shared points of interests (Cicognani et al., 2008). Student activism represents this kind of belonging, too, but it is also closely connected with the concept of active citizenship (Birdwell, Scott, \& Horley, 2013). According to Delanty (2003), learning active citizenship is a process, which we here understand as a developmental process. Development is comprehensive, and includes, for example, the ability to successfully face various crises and injustices. Park (2004) points out that:

Life is full of challenges-stresses and risks, both major and minor. Facing such challenges is part of growing up. Neither society nor parents can completely protect children from them, and it is, after all, the children and youth who themselves have to meet these challenges. However, we can prepare them to overcome adversities in life and furthermore to thrive. (p. 51)

One positive outcome of development is becoming a responsible and active citizen, which is considered one of the important element of a human being's well-being (Seligman, 2011).

The purpose of this study is to analyze university student activists' participation in student activism and their development in it as the manifestation of positive youth development. Finnish universities have student organizations focusing on various themes, such as numerous study programs and departments, hobbies, culture, and recreation. In addition, there are campus-specific organizations, international study organizations, sport and sport club organizations, political and societal organizations, and religious organizations. Moreover, each university has a student union that must be formed according to the Universities Act (46§). The task of a student union is to promote students' societal, social, and mental aspirations, as well as their studies and position in society. The student unions participate in the educational task of university by preparing students for active, aware, and critical citizenship.

The decision-making organ of a student union is the representatives elected by an election. Student unions also have boards of directors (later referred as "board") and other organs. Finnish student unions are special 
Finnish student activists' resources in student union activities: A Positive Youth Development perspective

when compared to unions internationally because each and every university student must be a member of a student union, and the membership has a yearly fee, charged by universities (Universities Act; Mäenpää 2009; see also Ansala, Uusiautti, \& Määttä, 2016).

In this study, the concept of student activism refers to active participation in student organizations in Finnish universities. The study contributes new viewpoints to how to support, strengthen, and maintain the youth's participation and positive development in universities and other education institutions as well as in society in general (see also Park, 2004). The positive psychological perspective that is adopted in the study highlights what is desired and good in youth development (see also Linley, Joseph, Harrington, \& Wood, 2006). Indeed, according to Lerner (2009), youth research should aim at enhancing youth development by guiding how to define societal goals that are to support positive development.

\section{Theoretical Background}

The definitions of adolescence or youth vary, and there are numerous theories about human development during adolescence and early adulthood. For example, according to Erikson's (1994) well-known theory, adolescence begins after school age and precedes (early) adulthood. Arnett (2000) launched the concept of emerging adulthood to describe development for the period from the late teenage through the twenties focusing on ages 18-25. Arnett's (2000; see also Arnett, 2007) purpose was to identify a special category for young people who do not see themselves as adolescents, but not entirely as adults either. However, the definitions place the phases of adolescence and early adulthood as a sort of intermediate phase between childhood and adulthood (Nivala \& Saastamoinen, 2010; see also Aittola, 1986). Likewise, university studies present an intermediate phase that takes place in adolescence or early adulthood.

Commonly youth theories illustrate, for example, the developmental challenges and crises that may be difficult for young people (Arnett, 2007). They also focus on core developmental tasks, such as accepting responsibility for one's self and making independent decisions (Arnett, 2000). There has also been a shift in youth studies, as pointed out by Pittman, Irby, and Ferber (2001); the focus has turned more and more on ways to promote development of such characteristics that are desirable in today's society. However, Catalano et al.'s (2002) review on youth studies suggest that focusing on promoting protection and reducing risk is likely to prevent problems and promote positive youth development, and that these viewpoints are fundamentally relatively similar.

In all, a human being's development from a child into an adult is a long and multidimensional process in which numerous factors have their own influence. These factors include, for example, resources in one's environment (e.g., school, family, society) and one's personal abilities and resources (e.g., self-regulation) (Urban, Lewin-Bizan \& Lerner, 2010). We consider youth development context-bound to a large extent, as human development happens in context and in interaction with it (Magnusson \& Mahoney, 2003; Urban, Lewin-Bizan \& Lerner, 2010).

Development in any phase of life necessitates various resources, including adolescence, that emerge and are used in developmental processes aiming at positive functioning (Magnusson \& Mahoney, 2003). These resources can be defined in multiple ways. For example, positive emotions, positive relationships, sufficient self-regulation and self-respect, and self-fulfillment are such resources (Uusiautti \& Määttä, 2013). These resources represent four elements of necessary human resources: social, emotional, cognitive, and functional resources (Määttä \& Uusiautti, 2012). Social resources include interaction skills, patience, caring, empathy, and social intelligence that help creating and maintaining good and reciprocal relationships. Emotional resources refer to positive emotions that foster coping and optimistic attitude in life. Cognitive resources are important to intellectual development. These resources include self-regulation and self-control, self-respect, motivation, and self-esteem. Functional resources represent the opportunity to use one's strengths at work, leisure, school, etc. At its best, using one's strengths can lead to experiences of self-fulfillment and the state of flow (Määttä \& Uusiautti, 2012). 
One way of analyzing positive resources and development is the Positive Youth Development (PYD) theory that is based on positive psychological thinking (Lerner, 2009; see also Lerner et al., 2010). Positive psychology refers to a wide spectrum of concepts that describe positive emotions, character strengths, and positive institutions (see e.g., Seligman et al., 2005; Seligman \& Csikszentmihalyi, 2000) that enable human beings' optimal, positive action (see Gable \& Haidt, 2005; Linley et al., 2006). One of the developmental tasks the youth face is the ability to engage to ethically high goals (e.g., Kahne \& Sporte, 2008). This viewpoint thus includes the societal perspective as well. In this case, we are interested in the connection of positive youth development and active citizenship development as it appears in university student activists (cf. Park, 2004).

The purpose of the PYD theory is to define positive resources that support development in adolescence (Lerner, 2009). In line with the basic assumptions of positive psychology (e.g., Seligman, 2011), the PYD theory emphasizes that all adolescents have strengths and that thriving is possible for everyone. According to the theory, it is possible to spot positive resources that support youth's positive development by analyzing youth's action (Lerner, 2009). Although every young human being has his or her personal developmental path, the theory suggests that positive development includes certain features that are called the five Cs. They are Competence, Confidence, Connection, Character, and Caring (see Table 1). These five attributes are considered to mark a flourishing young person (e.g., Eccles et al., 2003; Lerner et al., 2005; Zarrett \& Lerner, 2008). According to for example Rathunde and Csikszentmihalyi (2006), if a young person manifests these crucial characteristics, he or she is likely to develop positively toward the so-called idealized adulthood. As mentioned, active citizenship can be seen as a part of it as well.

An important perspective in PYD is that it also introduces a sixth C, which is Contributions (see Table 1). It means that the healthy and positive development is marked by contributions to self, family, community, and civil society (Lerner et al., 2010; Lerner et al., 2011). This contribution can appear in multiple ways, such as the ability to keep oneself fit and healthy and thus not burdening the resources of others unnecessarily, or by contributing to common good by showing willingness to help and assist other, and to volunteer. Other ways of contributing are, for example, to act to support the institution of democracy by participating in political debate and political activism (Lerner et al., 2010). In this perspective, the PYD theory provides a usable foundation to analyze the resources and development in university student activists as they learn and develop toward active citizenship.

\section{Table 1}

The 5 Cs and the sixth C of Positive Youth Development theory (Zarrett \& Lerner, 2008)

\begin{tabular}{cl}
\hline "C" & \multicolumn{1}{c}{ Definition } \\
\hline Competence: & $\begin{array}{l}\text { Positive view of one's actions in specific areas, including social, academic, cognitive, } \\
\text { health, and vocational. Social competence refers to interpersonal skills (such as } \\
\text { conflict resolution). Cognitive competence refers to cognitive abilities (e.g., decision } \\
\text { making). Academic competence refers to school performance as shown, in part, by } \\
\text { school grades, attendance, and test scores. Health competence involves using nutrition, } \\
\text { exercise, and rest to keep oneself fit. Vocational competence involves work habits and } \\
\text { explorations of career choices. }\end{array}$ \\
An internal sense of overall positive self-worth and self-efficacy. \\
Confidence: & $\begin{array}{l}\text { Positive bonds with people and institutions that are reflected in exchanges between the } \\
\text { individual and his or her peers, family, school, and community in which both parties } \\
\text { contribute to the relationship. } \\
\text { Respect for societal and cultural norms, possession of standards for correct behaviors, } \\
\text { a sense of right and wrong (morality), and integrity. } \\
\text { A sense of sympathy and empathy for others. }\end{array}$ \\
& \\
Caring/Compassion: & \\
Contribution &
\end{tabular}


Finnish student activists' resources in student union activities: A Positive Youth Development perspective

What is important in the context of this study, is that the PYD also recognizes that extracurricular activities enhance youth development (Eccles \& Gootman, 2002), although not all hobbies contribute similarly to development (Urban, Lewin-Bizan, \& Lerner, 2010).

According to the PYD theory, politics should not only function to prevent problems but also to support activities taking place outside schools and where positive development happens (Lerner et al., 2010). According to our understanding, the PYD-theory fits well with the age range of Finnish university students. University studies is a life phase and provides a possibility for positive growth and development. During university studies and organizational activities students face challenges. This research gives voice to these students, their stories of challenges faced, resources used, positive emotions, character strengths and enabling institutions. Student activism has been less studied in Finland, except the Finnish Student Barometer Surveys (see e.g., Saari \& Kettunen, 2013). Therefore, this study contributes by analyzing student activism experiences with qualitative research methods that make it possible to reach the student activists' own perceptions, opinions, and experiences.

One of the most famous research on the application of PYD is likely to be the 4-H study by Lerner and his colleagues (see e.g., Lerner, 2004; Lerner et al., 2005). The 4-H study was designed to test the idea that when the strengths of youth are aligned across adolescence with family, school, and community resources positive youth development and youth community contributions will occur. In the study, positive youth development was operationalized with the five Cs and the sixth $\mathrm{C}$ mentioned in Table 1. In our study, we explored the construction of the link between individuals and their context to the course of PYD (see Lerner et al., 2010). To conquer the challenges participation in student unions introduce, university student activists need certain resources that they have to employ positively.

\section{Method}

The purpose of this study is to analyze what kinds of challenges university student activists have faced in organizational activities, and how they describe the challenges and their ways of coping with them. The viewpoint provides a way to understand the development toward active citizenship and to help supporting students in their positive development. The following research questions were set for this study:

$>$ How do student activists describe challenges they have faced in the organizational activities?

$>$ What kinds of resources have they used for coping with the challenges?

The fundamental idea is that coping with challenges successfully can also be viewed as the manifestation of learning and positive development. The ultimate purpose is to analyze how the student activists' narratives illustrate the elements of positive youth development.

To answer these questions, this study employed the narrative research approach, the narrative inquiry, which has directed the selection of methodology, guided data collection, analysis and interpretation (see Stitt \& Winsor, 2014). We wanted to allow the research participants to construct their own narratives and stories, and to interpret their own experiences. Narrative research has a constructivist nature: narratives are not actual events but personal illustrations about them (Bruner, 1987; Lieblich, Tuval-Mashiach, \& Zilber, 1998).

The narrative approach formed the basic element of this research as the data would be based on research participants' experiences and their own stories: the aim was to collect university students' narratives about challenges related to student activism and resources they used for coping.

This study took place in Finland that has 14 universities; thus, the student activists in these universities form the target group of the study. In this study, the chairperson of each student union in Finnish universities were recruited ( $\mathrm{N}=14$, one chairperson in each student union). The chairpersons were selected as the target group because they can be considered student activists who have proceeded well in their activists' careers since they have been selected through election in their positions. The research participants were approached with an email 
including a request to participate in a personal interview. Of 14 chairpersons, 12 participated in the interview. The two remaining chairpersons rejected the invitation due to busyness and lack of interest in the research.

Interviews were conducted face-to-face $(\mathrm{N}=2)$ or via Skype $(\mathrm{N}=10)$ in April-June 2014. The interviews lasted about one hour each. The interviews were recorded digitally and transcribed afterwards.

The participants were born in 1984-1991, so at the time of the interview, they were approximately 23-30 years old. Eight of the participants were men and four women. They represented 12 different universities in Finland. Four of the participants were from the capital city, Helsinki, and others evenly from other parts of Finland. Students in this study were mainly studying their 4 th year at the university.

Previous studies (Saari 2013; Kettunen \& Villa, 2013) on student activists in Finland have showed that men are somewhat more active than women. Students start their university studies at the age of 20 while the average age of students is 26 in Finland (Finnish Student Survey, 2014). In addition, children with academic parents participated in student activism more often than others. Activism varies by study programs as well. However, previous education, age, social well-being at the secondary education level, and the quality of the entrance examination at the university did not correlate with activism in students. In general, $43 \%$ of university students participate in student activism either actively or somewhat actively. (Saari, 2013; Kettunen \& Villa, 2013.) In this study, the influence of students' social backgrounds was excluded from analysis.

The data were analyzed by using the analysis of narratives (see Polkinghorne, 1995). The analysis of narratives aimed at categorizing the narratives by themes or categories emerging from the contents (see also Mayring, 2000). In the first round of analysis, we discovered that the narratives could be categorized into the four resources described by Määttä and Uusiautti (2012). They describe the human's personal resources in a broad perspective and give a framework to take also the steps of analyzing our material. The resources are introduced as the four main categories of results. The categorization is based on the challenges and resources needed for coping with them as described in the data. According to our interpretation, the challenges and related resources could be seen as manifestations of development. Therefore, the initial analysis laid the foundation to further interpretation of the findings that pursued investigating how the elements of PYD could be identified from the narratives. In the second phase of analysis, we searched for elements that illustrated positive development as introduced in the PYD theory. In this sense, the data analyses were theory-led.

In all, when analyzing autobiographies, it is evident that people have various ways of producing narratives. Their stories differ from each other when it comes, for example, how much one reveals about a certain phase in life or an event. The thematic density is shown in written essays or stories as well. Some themes can be described quite superficially while others may be discussed in a very detailed or profound manner (Goodson, 2013). Although every person is different, everyone's stories tend to have somewhat similar plots that can be divided into various constructs (Goodson, 2013).

The head researcher of this study has participated in activism in various university organizations for seven years, which covers the years of her university studies. Due to her background, she knew one of the research participants beforehand. Her personal experiences influenced the selection of the study theme and her wish to be able to develop active citizenship. While her background might influence the objectivity of data collection and analyses, it also provides means to understand the world of student activism and make interpretations. Therefore, it is merely a question of finding the right dimensions between proximity and distance with the subject. Careful reflection on the researcher's relationship with the theme is crucial (Ben-Ari \& Enosh, 2011). To enhance the objectivity of the study, the results and study processes have been reported as explicitly as possible (Denzin \& Lincoln, 2008). Profound understanding also creates a sense of familiarity with the theme (see Cetrez, 2005). In addition, collaboration with a research group that have studied student activism in Finland was to increase the trustworthiness of the study. 


\section{Results}

The student activists' narratives highlighted many various challenges related to the everyday work in student unions. The challenges and coping with them could be categorized into four main themes: cognitive, social, emotional, and functional challenges.

\subsection{Cognitive Challenges and Resources}

Cognitive challenges appeared the largest theme in the data. Altogether 12 interviewees described challenges related to personal well-being and self-regulation. Many of the student activists had experienced difficulties in time and stress management. Serving as a chair of the student union is demanding and laborious, and as one of the interviewees pointed out "this work is draining".

One of the core issues was handling busy schedules and coping with stress. The student activists described their weekdays pressing:

At least this year, I have had such busy days that I have been able to have only like one 10-15-minute-long break a day. Therefore, you do not have time to go and have some lunch, and then you just pass the lunch and exercising and so on. (Student activist no. 12)

Time management necessitated the prioritization of activities. The student activists often described this when they discussed how to use their time efficiently. Sometimes, the busy everyday life meant that proper dining, sleep, exercising, and socializing with friends and family members were put aside. Living out of a suitcase is not just for businessmen and women but also student activists had experienced this life style.

I have my suitcase always ready. I live out of a suitcase, and my home is not my home but a storage unit of the important things in my life. (Student activist no. 10)

According to student activists' descriptions, student activism requires the ability of receive criticism and make compromises in different phases of the operation. For example, they mentioned elections that test students' self-regulation skills. Under the pressure of being a candidate in the election one have to be prepared for various kinds of challenging situations, including becoming rejected. The chairpersons are usually selected at the meeting of the student union representatives. Student activists surfaced that applying for the chairperson's position or other positions related to student activism are challenging. Both wins and losses were faced during elections:

Of course, along the way, I have faced new challenges when I have wanted to get harder tasks. I mean, how you can get there in the first place, do you believe in yourself enough. That has been a little question, especially, when I applied for this. Am I good enough and do I have what it takes. (Student activist no. 7)

The interviews showed that student activists' self-regulation and personal well-being skills varied. Some students told how they had recognized the challenges and influence of student activism to their personal well-being and balance in life. These students did not describe in a very positive manner their coping with challenges. Although they recognized the need for using better cognitive coping skills, such as time management, they were not always able to act accordingly.

Researcher: We were talking about how you cope with the time management challenge?

Student Activist: Well, by giving up the regular sleep rhythm, dining, and using time for voluntary scientific and artistic work. All this would keep up your work ability in the long run. Now, you clip off from your future self, hoping that you can rest a little in the summer. You sort of make your schedules tighter and tighter, and basically cut down everything a little. Currently, my days 
can be over 12 hours long, running from a meeting to another, and, if I am very lucky, I may be able to write the next meeting's agenda at some point. (Student activist no. 9)

Several student activists also described in the interviews how their self-regulation skills and means of enhancing their personal well-being had developed. Setting up schedules and sticking to them illustrate concrete means to regulate one's own activities and to increase personal well-being. Self-regulation includes that one knows one's limits and the healthy balance between organizational activities, studies, and other areas of life. For instance, one student described how she checked her weekly and monthly schedules every Sunday. Another student activist listed shared discussion moments with others, jogging, and trips elsewhere as means to regulate stress and maintain well-being. Also importance of understanding the value of a good night sleep was mentioned in the data:

I have learned to put my phone on a silent mode for night, because I know that sleep should not be disturbed. (Student activist no. 10)

\subsection{Social Challenges and Resources}

Student activism means basically working with other people. For many of the student activists, friendships had been the major motive to participate in activism (Ansala, Uusiautti, \& Määttä, 2016). However, friendships and collaboration with others become challenged in organizational activities; students differ in their opinions and attitudes and collaboration necessitates well-developed social skills. Altogether eleven of the twelve interviewees described social challenges in organizational activities. Student activism was seen as a meeting point of various kinds of people, and conflicts could not always be avoided:

Here, you meet people who come from a totally different world, and you have to get along with them and collaborate to do these tasks. It has been beneficial to be obliged to work with very different kinds of people and learned to get along, but then again, you face quite hard conflict situations or collisions. So, that has been even surprising to me, and you have not been prepared for it until you have been here and realized that you are not working here with people who have similar opinions. Before these activities, you could choose your company better. On the other hand, you cannot always win. (Student activist no. 5)

The interviewees told that, like in any shared activities, also student organizations get together different people and values. One of the chairpersons described how challenging but important it was to smooth over these values and opinions in a smart way. Everyone are not able to or cannot work similarly, and accepting other methods and approaches was considered crucial. One of the students told that mediating between various student activists and acting in the chairperson's role were extremely challenging:

And now I remember that good challenge in the student union. We have quite different kinds of agents and various people, quite different values on the table: how do you align all these common or conflicting opinions so that you find the common path there, and how to find it in an important, smart, and objective manner. (Student activist no.6)

Likewise, the means to cope with social challenges were versatile. Support from their close ones was mentioned by several student activists. Sometimes, the interviewees even had their own spouse, girlfriend or boyfriend participating in the activities. Sharing the world of student activism could not only provide support but also strengthen their relationship. Other positive relationships, such as friendships, were also considered important social resources providing perspectives to handle the tricky situations (see also Carr, 2011).

However, the most important resource was development in various social skills. For example, one of the interviewees described her own social intelligence and its development:

You know, I am quite a quick-tempered person, and I have had to keep it under control, 
Finnish student activists' resources in student union activities: A Positive Youth Development perspective

especially now that I am the chairperson. But I think that I have found quite a good balance, that when I discuss with people and when there is some serious issue or when discussing at meetings, I keep calm and objective. But I admit that, every now and then, some four-letter words are being said in the board's meeting room. But I have not received any negative feedback; instead, people have said that it is refreshing when someone shows her feelings. (Student activist no. 2)

The aforementioned data excerpt describes the chairperson's ability to regulate her behavior and emotions according to the situation. The interviewees described also the development of their listening skills and empathy. They are important areas of social skills (see e.g., Riggio, 2014) that lay the foundation for creating, acting in, and maintaining social relationships and networks.

In addition, the student activists described that the group of chairpersons of the Finnish student unions formed one social resource for them, as they meet each other several times a year. Furthermore, the positive learning experiences included student activists' need for reasoning their arguments as the challenges in social relationships in the student unions often related to differences in opinions and disagreements in decision-making situations. According to the data, these challenges were surpassed when they had learned argumentation and negotiation skills.

\subsection{Functional Challenges and Resources}

This category included the norms, rules, and methods of student unions and the ability to adopt and follow them. The board members serve as supervisors of the union secretary and union employees. In addition, the chairpersons, in the role of the board supervisor, are responsible for organizing the operation. The so-called supervisor's role had, indeed, been challenging to adopt as being one was a new experience for the chairpersons. Altogether seven interviewees described functional challenges. They found the supervisor's role a new and challenging place for learning:

Another thing in this student union business that I have learned at the beginning of this year is that you are in an employer's position in the organizational activities. That is totally new, and probably a challenge for many of us. And I think it has been an interesting challenge, and I have learned a lot from it. (Student activist no. 1)

The supervisor's position includes that the chairpersons lead other board members' work. The chairperson's are also expected to develop the activities and take care of that everyone does their tasks. However, this is not always the case. One student activist described leading the board members as a hot situation:

Yeah...Hmm... They are, those discussions, if you have to say someone something really difficult, and it is not necessarily that scary but it is really a hot situation. I had to face it with a couple of board members. I had to discuss what being a member of the board means and so on, and that was really nerve-wracking; am I able to express myself clearly so that they understand that there is problem that has to be fixed. So that they would not be totally depressed after the discussion. I was afraid of that. (Student activist no. 2)

The board members also form the organ for operative management in the student unions. In a trustee organization-like student unions are-this can mean, for example, that they have to give quick statements about issues. In order to cope with such challenges, the interviewees described how they made decisions based on best possible information.

Functional resources refer to action in which people have the chance to use their abilities widely and be in first name's terms with their roles. This leads to the sense of meaning in their action. Similarly, the recognition of one's own strengths is essential in student activism (e.g., Seligman, 2011). Coping with functional challenges means that the chairperson has started to adopt the roles and norms related to the organizational activities. 
Ansala, L., \& Uusiautti, S.

Positive experiences occur when they notice development in their skills and find themselves more and more self-confident in various situations:

I think that every time I have faced these [challenges] the easier it is to find out that you have kind of gotten used to it. You just handle it somehow, you are kind of used to go into that situation and have an understanding that becoming too stressed and such is not benefitting you in any way. (Student activist no. 8)

\subsection{Emotional Challenges and Resources}

According to the interview data, organizational activities is challenging emotionally, too. Here, we refer to such challenges that have been experienced negatively or have caused negative emotions in student activists. Such emotions are, for example, fear or hatred, and they were especially related to the relationship between representatives and the board of the student union. The representatives are selected by election and they have the highest decision-making power in student unions. The representatives have the power to choose and dissolve the board, which was described as quite a stressful side of student activism. Likewise, the representatives have the power to decide, for example, about the strategy of the student union and membership fees. In addition, they control the board activities. Different kinds of meetings were considered emotionally challenging, and at their worst, even causing fear in the interviewees. Similarly, they had found various interaction situations tense, because their expertise and capabilities were tested. Seven of the interviewees mentioned these kinds of emotional challenges and described them for example as follows:

Then again, I am a little scared in the meetings with the representatives, although none of our boards has been dissolved during the past twenty years. But basically, I have to be the one who can answer all these questions. So, if I freeze totally, which has not happened and everything has gone always really well, but still. It is straining. (Student activist no. 2)

The relationship between the board and the representatives is apparently quite complex. Cooperation and distribution of work have their own challenges, and every now then, tempers fray. On the other hand, the chairpersons described their feelings of frustration and becoming nullified. They had even been threatened. The following data excerpt illustrates the emotional strain one chairperson had experienced:

Well, we have the representatives who have started to define themselves strictly to left and strictly to right, and then again, the biggest groups are the study program related groups that do not have the political passion to plead a cause like that. So, then the battle between these two [political] groups has caused a situation in which the board is drawn in the middle without asking from us, and then they get personal. So, perhaps that is a challenge because we do not know anymore what our role is there. They can give us a task based on their own desires, like "let's throw this to the board, they do and figure it out". That is something that makes me want to chastise them because it gets ridiculous, a sort of show. And then they cannot make decisions because the representatives of the study programs do not want to participate in it. So that is something that is a sort of a challenge. (Student activist no. 4)

The way the student activists coped with emotional challenges showed that the survival from them turned into positive resources. The negative emotions disappeared after handling tricky situations and almost always turned into positive emotions. What was considered important was to draw from these positive experiences of coping instead of chewing over negative emotions and letting the frustration or fear control you. The chairpersons described how they had learned to face emotional challenges and regulate their feelings. Each challenge could lead to new opportunities. The interviewees also emphasized that peers formed an important channel to analyze situations and discuss emotions and experiences in a safe and encouraging manner. Friends and their own boards could be the valuable peer support: 
We have always had our own relaxed evening parties where we discuss how the meeting went and what thoughts they had. So that no one will be thinking alone that "I received negative feedback" and "is this really serious" and whatever. We discuss it together with the whole group. Then we all support each other so that no one will be like "oh no, we have the meeting with the representatives again, I do not want to go and listen to that tongue-lashing there" and so on. And this is how we have handled it together. (Student activist no. 4)

\section{Discussion}

Like the findings show, organizational activities are varying and tasks are challenging. Student activists face many kinds of challenges that they handle with various resources. Next, their coping is viewed from the perspective of positive youth development. The purpose is to analyze how the areas of positive development appeared in the chairpersons' narratives.

Competence - The student activists' interviews had a positive tone. In many ways, the data showed positive ways of describing their own action, coping, learning experiences, and, for example, their future aspirations. According to the findings, the student activists' competence developed at several levels. They explained how their social competences increased when handling challenging social situations with other student activists. Student activists concretely described situations where they had to resolve conflicts related from minor matters such as ordering hooded jackets for the team to bigger issues such as collaboration with the representatives. Cognitive competences include, for example, decision-making skills. Student activists described how fast decision-making was challenging, but learnable. In this study, the development of academic competence was not measured but apparently skills the activists had learned through organizational activities benefit their studies as well (see e.g., Rosas, 2010). Health competence appeared in the student activists' descriptions of how they had learned time management skills and to care for their physical shape and sufficient sleep in order to maintain their well-being. The student activists had also increase in their vocational competence as they learned many useful skills, such as interaction skills and negotiation skills. Indeed, it has been proved that student activists have better vocational competences than their non-activist peers (see Saari, 2013).

Confidence - Coping with challenges was described as positive learning experiences that boosted the student activists' self-confidence and their self-appreciation as chairpersons. This kind of positive attitude toward oneself develops especially through one's own development. Stronger self-confidence in student activism makes facing new challenges easier and also increases motivation and drive to do the activities. The development of the sense of self-worth and self-confidence was manifested in the desire and ability to continue and even to apply for next challenging positions and tasks in the student union. The increase in self-confidence also increased trust in one's action and its right direction.

Connection - As the findings showed, social relationships played a big role in student activism-in good and in bad. Student activists emphasized the meaning of social relationships already when finding their way to the organizational activities (see Ansala, Uusiautti, \& Määttä, 2016). At their best, social network formed reciprocal relationships that allow student activists reflect on their action. They also learned skills of interacting with various kinds of people successfully.

Character - The element of character in positive youth development appeared in the student activists' descriptions of how they developed as chairpersons and adopted the role. This was strongly related to their ability to adopt and follow the norms and rules of the organizational activities, in other words, to internalize this specific operation culture. Positive development led to the realization of how to act as a chairperson, be objective and give feedback to board members. Positive learning experiences and resources strengthened their character as chairpersons.

Caring - Caring is another element of positive development. The interviewees expressed caring for other students and members of the student union. Caring appeared as their wish to improve the study environment (see 
Ansala, L., \& Uusiautti, S.

also Ansala, Uusiautti, \& Määttä, 2016) and in natural leading situations in which they wanted to encourage others to better performances or action for the common goals. The chairpersons also showed caring through their wish to act righteously and fairly. Consequently, their development manifested higher level caring, namely caring active citizenship.

Contributions - The theory of positive youth development suggests that there also is the sixth element of development, contributions. Contributions refer to aspiration to improve one's personal life as well as that of one's loved ones but also to contribute wider in society. This is an extremely interesting area of positive development when analyzing student activists. When considering the development in student activists in the light of this study, it became evident that student activism developed social, cognitive, functional, and emotional resources in student activists. They all are important for maturing in general, but this study illustrates what they mean especially for the development of active citizenship in students.

\section{Conclusions}

The student activists' narratives illustrate students' everyday life in many ways, including the challenges they face. Student activism affects in many areas of life that were here divided into cognitive, functional, social, and emotional challenges. Positive development in these areas necessitate various kinds of resources and strength. However, student activism appeared as an opportunity to learn and use these strengths, thus representing an arena of positive development. The especial focus in this study was to identify those positive resources that support the development of active citizenship in students. From an individual student's perspective this happened in many levels.

The findings of this study are in line with a large, longitudinal 4-H study (see e.g., Lerner et al., 2010), that showed the importance of activities taking place outside school for positive youth development. Encouraged by the findings, it seems that as these kinds of activities enhance the development of active citizenship in students and as this is one of the objectives of formal education, these activities should be supported actively. As the research shows, the positive development of five Cs leads to the contributions to self, family, community, and civil society. The ability to contribute is the foundation of not only personal well-being but societal well-being as well, as it is manifested as the aspiration to enhance one's own and communal success. This analysis of contribution (the sixth $\mathrm{C}$ ) introduces a new viewpoint to the connection between positive youth development and student activism and active citizenship.

Participation in organizational activities supports students' development and growth in many ways, which means it is extremely relevant to consider ways to enhance societal participation by offering different opportunities to learn it (see also Kennedy, 2007; Zaff et al., 2010). Lerner (2009) points out that

[a]s such, the PYD perspective suggests that, if we are to conduct good science about adolescent development, we must study youth and context in integrative, developmental manners. Such work can inform policies and programs uniquely, helping to characterize the multiple ways that the strengths of diverse youth can be transformed into positive developmental pathways. - Continued scholarly and societal investment in such work can enhance the likelihood that strong, active, and contributing youth will be emblematic of the future of civil society. (p. 161)

To conclude, one of the central goals of politics and the school system would be-following the idea of the positive youth development theory-to create such opportunities to the youth that would help them develop and flourish in the elements of PYD. Student activism appears as one option of extracurricular activities (see also Urban, Lewin-Bizan, \& Lerner, 2010) that also has a special emphasis on the development in contributions, in the sense of developed active citizenship.

As the study showed, the process of learning active citizenship skills is challenging and multidimensional. However, a constructive and critical engagement with politics and communal affairs is an essential feature of the 
Finnish student activists' resources in student union activities: A Positive Youth Development perspective

citizens that schools should promote (Arthur \& Croll, 2007). However, universities should, even in times of efficient study processes and tightening graduation schedules, realize that the opportunities to participate in extracurricular activities are important for the holistic well-being and development of positive resources in students.

\section{References}

Aittola, T. (1986). University studies as a life phase. A pre-study report [In Finnish]. Jyväskylä: University of Jyväskylä.

Ansala, L., Uusiautti, S., \& Määttä, K. (2016). What are Finnish university students' motives for participating in student activism? International Journal of Adolescence and Youth. http://dx.doi.org/10.1080/02673843.2015.1044015

Ansala, L., Uusiautti, S., \& Määttä, K. (2016). Student unions as the way of learning democracy skills Successful Finnish university student activists' perceptions. International Journal of Arts \& Sciences, $8(6), 31-44$.

Arnett, J. J. (2000). Emerging adulthood. A theory of development from the late teens through the twenties. American Psychologist, 55(5), 469-480. http://dx.doi.org/10.1037/0003-066X.55.5.469

Arnett, J. J. (2007). Emerging adulthood: What is it, and what is it good for? Child Development Perspective, 1(2), 68-73. http://dx.doi.org/10.1111/j.1750-8606.2007.00016.x

Arthur, J., \& Croll, P. (2007). Citizenship, democracy and education. British Journal of Educational Studies, 55(3), 233-234. http://dx.doi.org/10.1111/j.1467-8527.2007.00376.x

Ben-Ari, A., \& Enosh, G. (2011). Processes of reflectivity. Knowledge construction in qualitative research. Qualitative Social Work, 10(2), 152-171. http://dx.doi.org/10.1177/1473325010369024

Birdwell, J., Scott, R. \& Horley, E. (2013). Active citizenship, education and service learning. Education, Citizenship and Social Justice, 8(2), 185-199. http://dx.doi.org/10.1177/1746197913483683

Bruner, J. (1987). Life as narrative. Social Research, 54(1), 11-32.

Carr, A. (2011). Positive psychology. The science of happiness and human strengths (2nd ed.) New York, NY: Routledge.

Catalano, R. F., Hawkins, J. D., Berglund, M. L., Pollard, J. A., \& Arthur, M. W. (2002). Prevention science and positive youth development: competitive or cooperative frameworks? Journal of Adolescent Health, 31(6S), 230-239. http://dx.doi.org/10.1016/S1054-139X(02)00496-2

Cetrez, Ö. (2005). An insider at the margins: My position when researching within a community I belong to. In H. Helve (Ed.), Mixed methods in youth research (pp. 232-251). Tampere: Juvenes Print.

Cicognani, E., Pirini, C., Keyes, C., Joshanloo, M., Rostami, R., \& Nosratabadi, M. (2008). Social participation, sense of community and social well-being: A study on American, Italian and Iranian university students. Social Indicators Research, 89, 97-112. http://dx.doi.org/10.1007/s11205-007-9222-3

Delanty, G. (2003). Citizenship as a learning process: Disciplinary citizenship versus cultural citizenship. International Journal of Lifelong Education, 22(6), 597-605. http://dx.doi.org/10.1080/0260137032000138158

Denzin, N., \& Lincoln, Y. (2008). Introduction. The discipline and practice of qualitative research. In N. Denzin \& Y. Lincoln (Eds.), Collecting and interpreting qualitative materials (pp. 1-43). Thousand Oaks, CA: Sage.

Eccles, J. S., Barber, B. L., Stone, M., \& Hunt, J. (2003). Extracurricular activities and adolescent development. Journal of Social Issues, 59(4), 865-889. http://dx.doi.org/10.1046/j.0022-4537.2003.00095.x

Eccles, J. S., \& Gootman, J. A. (Eds.) (2002). Community programs to promote youth development. Washington, DC: National Academy Press.

Erikson, E. H. (1994). Identity and the life cycle. New York, NY: W. W. Norton \& Co.

Finnish Student Survey. (2014). Student income and factors that influence studies among students in higher education. Ministry of Education and Culture 2014:10 [In Finnish]. Kopijyvä Oy. Retrieved from http://www.minedu.fi/OPM/Julkaisut/2014/Opiskelijatutkimus_2014.html 
Ansala, L., \& Uusiautti, S.

Flanagan, C., \& Levine, P. (2010). Civic engagement and the transition to adulthood. Future of Children, 20(1), 159-179. http://dx.doi.org/10.1353/foc. 0.0043

Gable, S. L., \& Haidt, J. (2005). What (and why) is positive psychology? Review of General Psychology, 9(2), 103-110. http://dx.doi.org/10.1037/1089-2680.9.2.103

Goodson, I. F. (2013). Developing narrative theory. Life histories and personal representation. Abingdon: Routledge.

Kahne, J. E., \& Sporte, S. E. (2008). Developing citizens: The impact of civic learning opportunities on students' commitment to civic participation. American Educational Research Journal, 45(3), 738-766. http://dx.doi.org/10.3102/0002831208316951

Kennedy, K. J. (2007). Student constructions of "active citizenship": What does participation mean to students? British Journal of Educational Studies, 55(3), 304-324. http://dx.doi.org/10.1111/j.1467-8527.2007.00381.x

Kettunen, H., \& Villa, T. (2013). Katsaus opiskelijabarometrin teemoihin [Overview of the student barometer]. In J. Saari \& H. Kettunen (Eds.), Finnish student Barometer. Overview on higher education students' studies, life and welfare (pp. 22-75) [In Finnish]. Keuruu: Digipaino Keuruskopio.

Lerner, R. M. (2004). Liberty: Thriving and civic engagement among American youth. Thousand Oaks, CA: Sage.

Lerner, R. M. (2009). The Positive Youth Development perspective: Theoretical and Empirical bases of a strengths-based approach to adolescent development. In C. R. Snyder \& S. J. Lopez (Eds.), Oxford handbook of positive psychology (pp. 149-163). New York, NY: Oxford University Press. http://dx.doi.org/10.1093/oxfordhb/9780195187243.013.0014

Lerner, R. M., Almerigi, J., Theokas, C., \& Lerner, J. V. (2005). Positive youth development. A view of the issues. Journal of Early Adolescence, 25(1), 1-16. http://dx.doi.org/10.1177/0272431604273211

Lerner, R. M., Eye, A., Lerner, J., Lewin-Bizan, S., \& Bowers, E. P. (2010). Special issue introduction: The meaning and measurement of thriving: a view of the issues. Journal of Youth and Adolescence, 39, 707-719. http://dx.doi.org/10.1007/s10964-010-9531-8

Lerner, R. M., Lerner, J. V., von Eye, A., Bowers, E. P., \& Lewin-Bizan, S. (2011). Individual and contextual bases of thriving in adolescence: A view of the issues. Journal of Adolescence, 34(6), 1107-1114. http://dx.doi.org/10.1016/j.adolescence.2011.08.001

Lieblich, A., Tuval-Mashiach, R., \& Zilber, T. (1998). Narrative research. Reading, analysis, and interpretation. Thousand Oaks, CA: Sage. http://dx.doi.org/10.4135/9781412985253

Linley, A. C., Joseph, S., Harrington, S., \& Wood, A. M. (2006). Positive psychology: Past, present, and (possible) future. Journal of Positive Psychology, 1, 3-16. http://dx.doi.org/10.1080/17439760500372796

Magnusson, D., \& Mahoney, J. L. (2003). A holistic person approach for research on positive development. In L. G. Aspinwall \& U. M. Staudinger (Eds.), A psychology of human strengths. Fundamental questions and future directions for a positive psychology (pp. 227-244). Washington, DC: APA. http://dx.doi.org/10.1037/10566-016

Marshall, T. H. (1950). Citizenship and social class and other essays. Cambridge: Cambridge University Press

Mayring, P. (2000). Qualitative content analysis. Forum: Qualitative Social Research, 1(2). Retrieved from http://www.qualitative-research.net/index.php/fqs/article/view/1089/2385

Meglino, B. M., \& Korsgaard, A. (2004). Considering rational self-interest as a disposition: Organizational implications of other orientation. Journal of Applied Psychology, 89(6), 946-959.

http://dx.doi.org/10.1037/0021-9010.89.6.946

Mäenpää, O. (2009). Universities Act [In Finnish]. Helsinki: Talentum Media.

Määttä, K., \& Uusiautti, S. (2012). The four-leaf clover of human resources. Research Journal in Organizational Psychology \& Educational Studies, 1(1), 37-42.

Nivala, E., \& Saastamoinen, M. (2010). Nuorisokasvatuksen teorian kohde ja konteksti [Target and context of the youth development theory]. In E. Nivala \& M. Saastamoinen (Eds.), Theory of youth development grounds and statements (pp. 8-27) [In Finnish]. Helsinki: Helsinki University Press. 
Finnish student activists' resources in student union activities: A Positive Youth Development perspective

Park, N. (2004). Character strengths and positive youth development. Annals AAPSS, 581, 40-54. http://dx.doi.org/10.1177/0002716203260079

Pittman, K., Irby, M., \& Ferber, T. (2001). Unfinished business: Further reflections on a decade of promoting youth development. In P. L. Benson \& K. J. Pittman (Eds.), Trends in youth development: Visions, realities and challenges (pp. 17-64). Norwell, MA: Kluwer Academic Publishers. http://dx.doi.org/10.1007/978-1-4615-1459-6_1

Polkinghorne, D. E. (1995). Narrative configuration in qualitative analysis. Qualitative Studies in Education, 8(1), 5-23. http://dx.doi.org/10.1080/0951839950080103

Rathunde, K., \& Csikszentmihalyi, M. (2006). The developing person: An experiential perspective. In R. M. Lerner \& W. Damon (Eds.), Handbook of child psychology (6th ed., pp. 465-515). Hoboken, NJ: Wiley.

Riggio, R. E. (2014). What is social intelligence? Why does it matter? Psychology Today, June 3, 2014.

Ropers-Huilman, B., Carwile, L., \& Barnett, K. (2005). Student activists' characterizations of administrators in higher education: Perceptions of power in "the system". The Review of Higher Education, 28(3), 295-312. http://dx.doi.org/10.1353/rhe.2005.0012

Rosas, M. (2010). College student activism: an exploration of learning outcomes. (PhD Diss., University of Iowa). Retrieved from: http://ir.uiowa.edu/etd/589.

Saari, J. (2013). What follows from organizational activities? Aalto-University and the University of Helsinki students' experiences of organizational activities in the student barometer survey [In Finnish]. Retrieved from http://ayy.fi/wp-content/uploads/Mita_jarjestotoiminnasta_seuraa_raportti_2013.pdf

Saari, J., \& Kettunen, H. (Eds.) (2013). Finnish student barometer. Overview on higher education students' studies, life and welfare [In Finnish]. Keuruu: Digipaino Keuruskopio.

Seligman, M. E. P. (2011). Flourish: A visionary new understanding of happiness and well-being. New York, NY: FreePress.

Seligman, M. E. P., \& Csikszentmihalyi, M. (2000). Positive psychology. An introduction. American Psychologist, 55(1), 5-14. http://dx.doi.org/10.1037/0003-066X.55.1.5

Seligman, M. E. P., Steen, T. A., Park, N., \& Peterson, C. (2005). Positive psychology progress: Empirical validation of interventions. American Psychologist, 60(5), 410-421. http://dx.doi.org/10.1037/0003-066X.60.5.410

Stitt, R. L., \& Winsor, D .L. (2014). A narrative inquiry: the experience of first-generation college students. Sage research Method Cases Online. http://dx.doi.org/10.4135/978144627305014533912

Universities Act. (24.7.2009/558). Retrieved from http://finlex.fi/en/laki/kaannokset/2009/20090558

Urban, J. B., Lewin-Bizan, S., \& Lerner, R. M. (2010). The role of intentional self-regulation, lower neighborhood ecological assets, and activity involvement in youth developmental outcomes. Journal of Youth and Adolescence, 39, 783-800. http://dx.doi.org/10.1007/s10964-010-9549-y

Uusiautti, S., \& Määttä, K. (2013). How to promote the healthy development of human resources in children and youngsters? European Journal of Academic Research, 1(5), 212-221.

Zaff, J., Boyd, M., Li, Y., Lerner, J. V., \& Lerner, R. M. (2010). Active and engaged citizenship: Multi-group and longitudinal factorial analysis of an integrated construct of civic engagement. Journal of Youth \& Adolescence, 39, 736-750. http://dx.doi.org/10.1007/s10964-010-9541-6

Zarrett, N., \& Lerner, R. M. (2008). Ways to promote the positive development of children and youth. Retrieved from http://www.childtrends.org/wp-content/uploads/2013/01/Youth-Positive-Devlopment.pdf 
Ansala, L., \& Uusiautti, S. 